\title{
ISOLATION AND SCREENING OF EFFICIENCY OF PHOSPHATE SOLUBILIZING MICROBES
}

\author{
SANJOTHA P., MAHANTESH P. AND PATIL C.S.* \\ Department of Biotechnology B.V.Bhomraddy College, Bidar, Karnataka \\ *Corresponding Author: Email- drcspatil251@yahoo.co.in, drcspatil1960@gmail.com
}

Received: March 12, 2011; Accepted: April 23, 2011

\begin{abstract}
The soil in the identified saline was investigated for the study of phosphate solublization by fungi and bacteria. In the present study 107 samples were collected from saline affected area, among these samples, 33 $(30.80 \%)$ samples showed the ability to solubilize the inorganic insoluble phosphate. From the study it was observed that the fungi viz; Aspergillius spp., Penicillium spp. and Fusarium spp. have the more solubilizing ability of inorganic insoluble phosphate than bacteria, viz; B.subtilis, and B.megatherium. Hence the application of biofertilizer prepared by above mentioned fungi should be helpful to reduce the salinity of soil by neutralization phenomenon, because these microorganisms release the acid in very minute quantity in phosphate Solubilization.
\end{abstract}

Keywords: Phosphate solubilizing microorganism (PSM), acid production, Pikovskayas agar.

\section{INTRODUCTION}

Phosphorus is one of the major plant nutrients, second only to nitrogen in requirement. However, a greater part of soil phosphorus, approximately $95-99 \%$ is present in the form of insoluble phosphates and hence cannot be utilized by the plants [1]. To increase the availability of phosphorus for plants, large amounts of fertilizer are used on a regular basis. But after application, a large proportion of fertilizer phosphorus is quickly transferred to the insoluble form [2].

Therefore, very little percentage of the applied phosphorus is used, making continuous application necessary [3]. It has been reported that many soil fungi and bacteria can solubilize inorganic phosphates $[4,5]$. Phosphate solubilizing microorganisms (PSMs) play an important role in supplementing phosphorus to the plants, allowing a sustainable use of phosphate fertilizers $[6,8]$. Application of PSMs in the field has been reported to increase crop yield $[9,10]$. Several mechanisms like lowering of $\mathrm{pH}$ by acid production, ion chelation and exchange reactions in the growth environment have been reported to play a role in phosphate solublization by PSMs[11,12]. Fungi have been reported to possess

greater ability to solubilize insoluble phosphate than bacteria[13]. In the present study fungal strains having potential to solubilize insoluble phosphates were isolated.

\section{MATERIAL AND METHODS}

Collection of Sample: The soil samples were collected from depth of $6-15 \mathrm{~cm}$ from different agricultural land of villages of saline affected area of
Bidar, Karnataka. Samples were collected from rhizosphere of plant like, Wheat, Jowar, Orange, Sugarcane, Gram, Onion, Sunflower, Tomato, Tur and Cabbage.

Isolation of PSM: Fungal and bacterial strains were isolated from the saline soil of Bidar, Karnataka, after serial dilution of soil solution on potato dextrose agar (PDA) and nutrient agar (NA) respectively. Isolated predominant, morphologically distinct colonies were selected, purified by repeated culturing and maintained on PDA and NA slants at $400 \mathrm{C}$ isolates were identified by their colony characteristics, spore morphology and microscopic observations. The isolates were studied for phosphate solubilizing ability on Picovskayas (PKV) medium[14].

Identification of Fungi and Bacteria: For the identification of fungi, a drop of lactophenol cotton blue placed on glass slide, then growth of fungi has to be taken on the slide and cover with the cello tape to fix the growth on slide, and the slide then observed under low objective microscope and identified based upon their colony morphology and spore characteristics[15]. The isolated bacteria, identified by studying morphological characteristic in which gram staining, shape, spores and motility including catalase test, glucose, mannitol fermentation and Vogues Proskeurs (VP) test were present[15]. (Table 1) 
Comparative Efficiency Study: Efficiency study has been carried out by performing an experiment of halo zone formation around the fungal and bacterial growth after inoculated on Pikovskayas agar and incubated for $24 \mathrm{~h}, 48 \mathrm{~h}$ and $72 \mathrm{~h}$ at $280 \mathrm{c}$ (Fig.1) continuous observation, indicates phosphate solubilizing ability which observed by checking diameter of zone which were in increasing order at every day incubation. The zones were then compared to find phosphate solublization efficiency. Figure 2 shows the comparative efficiency of PSMs for 10 different samples.

\section{RESULTS AND DISCUSSIONS}

In the present study 107 soil samples were collected from different villages of Bidar, Karnataka 33 (30.80\%) samples showed presence of PSM. In the advance condition of $\mathrm{pH}$ the organisms isolated from salinityaffected soil indicates high salt and salinity tolerance, which can be used for preparation of biofertilizer from locally isolates. From the isolated sample, twenty villages (87\%) were found the Aspergillus spp. (Fig1: $1.1,1.2)$, two villages

(8.7\%) are found Penicillium spp. (Fig1: 1.3) and single village (4.3\%) was found Fusarium spp. (Fig1: 1.4) and ten villages were found the phosphate solubilizing bacteria i.e. Bacillus species, out of which seven villages (70\%) were found Bacillus subtilis and three villages (30\%) were found to be Bacillus megatherium. According to the laboratory experiment of phosphate solubilization, it was found that the fungi have more efficiency to solubilize the phosphate than bacteria. Hence there is need to develop the strain of fungi as phosphate fertilizer, also the application of the biofertilizer prepared by fungi should be helpful to reduce the salinity of soil by neutralization phenomenon, because these microorganisms release the acid in very minute quantity in phosphate Solubilization.

\section{REFERENCES}

[1] Vassileva M., Vassilev N. and Azcon R. (1998) World J. Microbiol. Biotech., 14: 281284.

[2] Omar S.A. (1998) World J. Microbiol. Biotech., 14: 211-218.

[3] Abd Alla M.H. (1994) Lett. Appl. Microbiol., 18: 294-296.

[4] Asea P.E.A., Kucey R.M.N., Stewart J.W.B. (1988) Soil Biol. Biochem., 20: 459-464.

[5] Singal R., Gupta R. and Saxena R.K., Folia (1994) Microbiol., 39: 33-36.

[6] Gyaneshwar P., Naresh K.G. and Parekh L.J. (1998) Curr. Sci., 74: 1097-1099.

[7] Kucey M.N., Janzen H.H. and Legett M.E. (1989) Adv. Agron, 42: 198-228.

[8] Tambekar D.H., Phosphate Solubilizing Microorganisms as Biofertilizer"Selected topics in Biotechnology, Ed. A. M. Deshmukh, PAMA Publications, Karad

[9] Toro M., Azcon R. and Barea J.M. (1997) Appl. Environ. Microbiol, 63: 4408-4412.

[10] Jones D.L. and Darrah P.R. (1994) Plant Soil, 166: 247-257.

[11] Yadav K.S. and Dadarwal K.R. (1997) Phosphate solubilization and. mobilization through soil microorganisms., Biotechnological Approaches in Soil.

[12] Dadarwal K.R. (1997) Microorganisms for Sustainable Crop Production, Scientific Publishers, and ISBN-13: 9788172331474, Jodhpur, 293-308.

[13] Cunningham J.E. and Kuiack C. (1992) Appl. Environ. Microbiol., 58: 1451-1458.

[14] Pikovskaya R.I. (1948) Microbiologiya, 17.

[15] Aneja K.R. (1998) "Experiments in Biology, Plant Pathology, Tissue Culture and Mushroom Cultivation." Second Edition. 


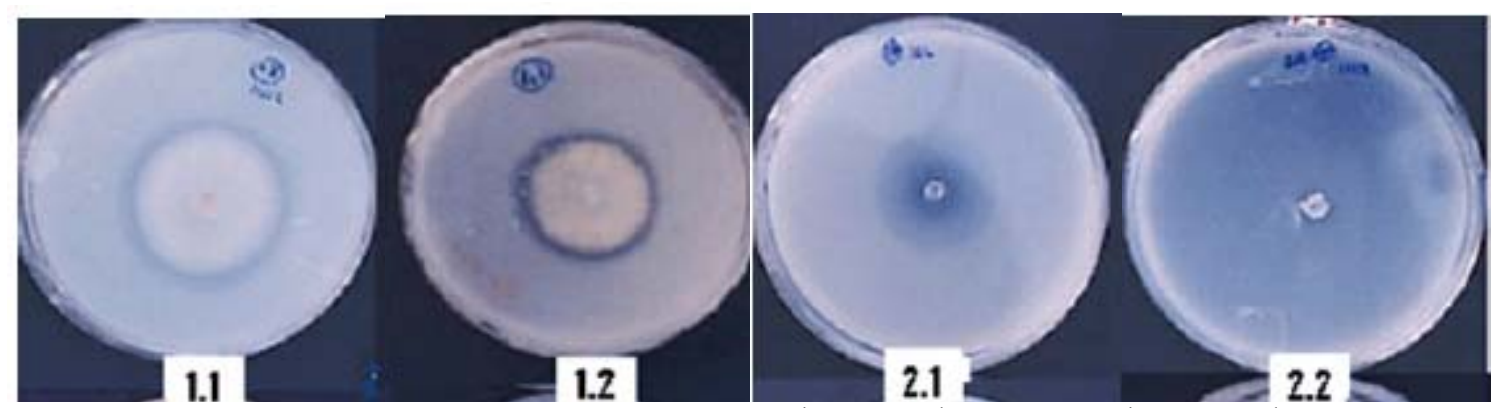

Fig. 1- Zone of Phosphate solublization by different fungi (1.1,and1.2) and bacteria (2.1 and 2.2) at 72hours

Table 1- Biochemical characteristics of PSB

\begin{tabular}{|c|l|l|c|c|c|c|c|c|}
\hline SI No & $\begin{array}{l}\text { Name of the } \\
\text { organism }\end{array}$ & $\begin{array}{l}\text { Gram } \\
\text { staining }\end{array}$ & spore & Motility & Catalase & Glucose & Mannitol & VP \\
\hline 1 & B.subtilis & Gram +ve rod & 0 & motile & 0 & $\mathrm{~A}$ & $\mathrm{~A}$ & 0 \\
\hline 2 & megatherium & Gram +ve rod & 0 & motile & 0 & $\mathrm{~A}$ & $\mathrm{~d}$ & \\
\hline
\end{tabular}

( $+=$ Positive, - = Negative, $A=$ Acid, $d=$ Doubtful)
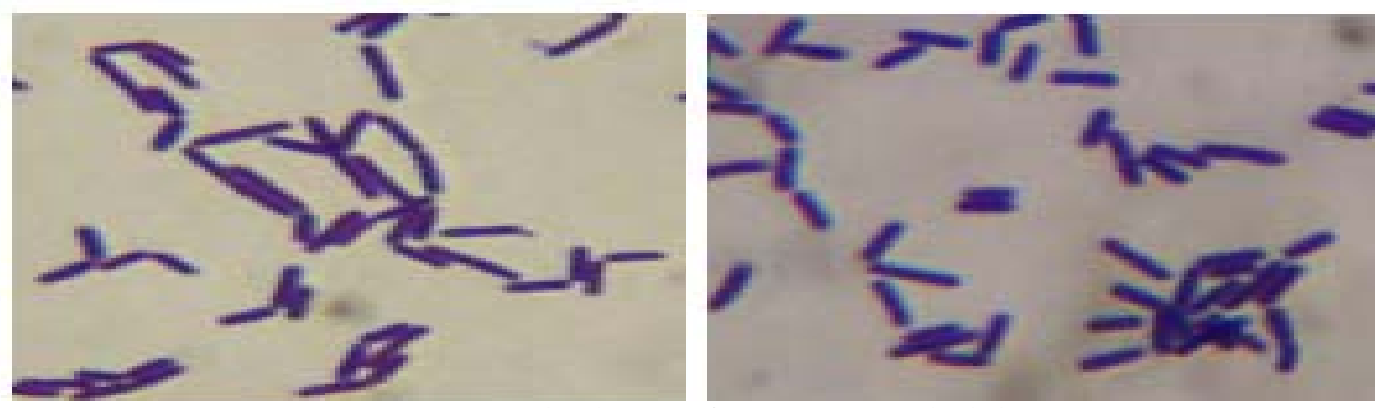

Fig. 2- Appearance Bacterial isolates as Gram Positive under light microscope.

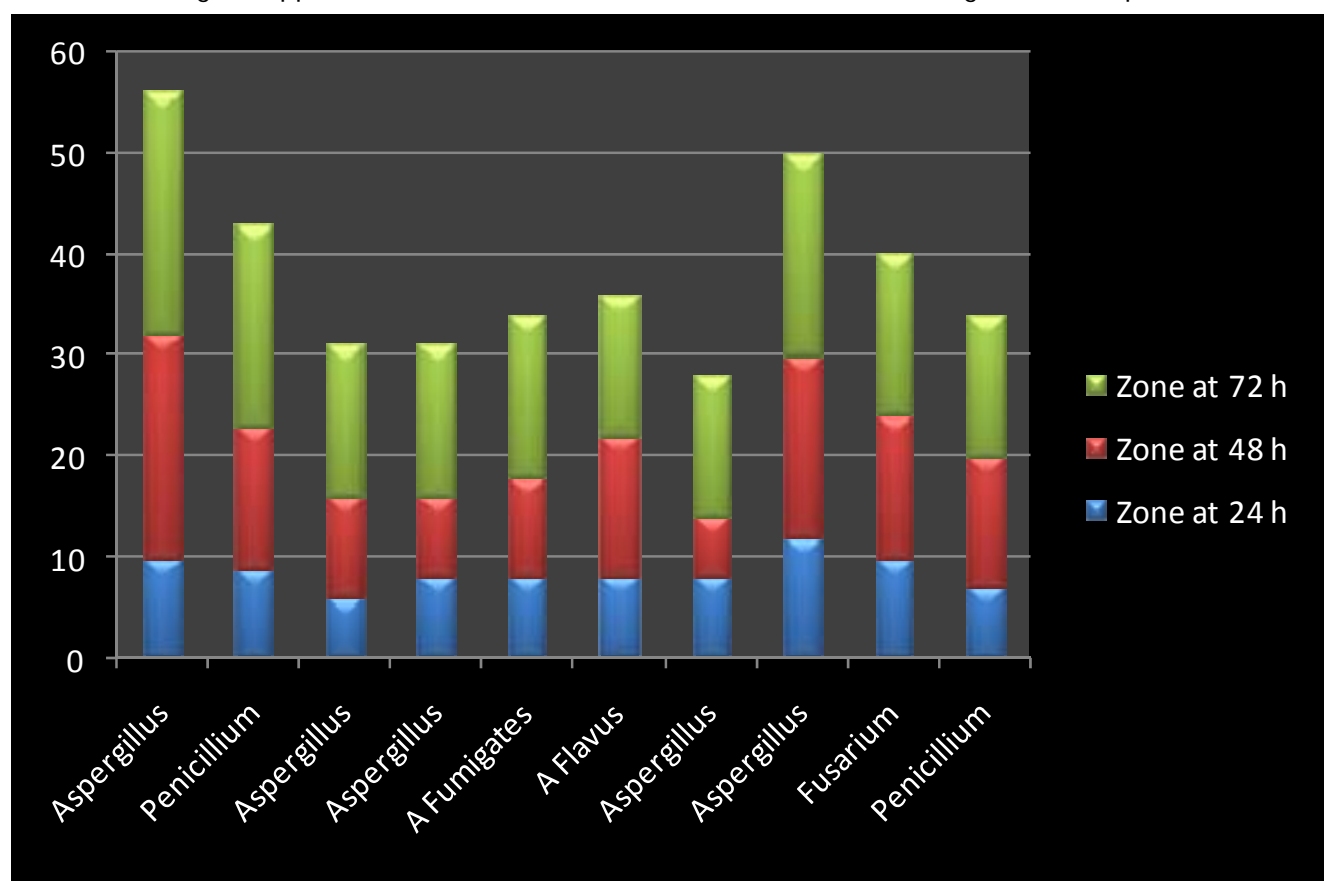

Fig. 3- Efficiency of Phosphate solublization by fungi and bacteria 